\title{
The production function and profitability analysis of Gracilaria sp. seaweed polyculture with milkfish (Chanos chanos) and black tiger shrimp (Penaeus monodon)
}

\author{
IIS DIATIN", IRZAL EFFENDI, MERI ALVINA TAUFIK \\ Department of Aquaculture, Faculty of Fisheries and Marine Science, Institut Pertanian Bogor. Jl. Agatis, Kampus IPB Darmaga, Bogor 16680, West \\ Java, Indonesia. Tel./fax.: +62-251-8622909, "email: iisdiatin@yahoo.co.id
}

Manuscript received: 1 June 2020. Revision accepted: 23 September 2020.

\begin{abstract}
Diatin I, Effendi I, Taufik MA. 2020. The production function and profitability analysis of Gracilaria sp. seaweed polyculture with milkfish (Chanos chanos) and black tiger shrimp (Penaeus monodon). Biodiversitas 21: 4747-4754. Gracilaria seaweed is the main ingredient for making agar as a source of food and industry. Gracilaria culture in ponds with a polyculture system is one of the potential seaweed cultivation in Indonesia. This study was aimed to analyze the productivity, production input optimation, and profitability on the polyculture system of Gracilaria sp. with milkfish (Chanos chanos) and black tiger shrimp (Penaeus monodon). The survey method was used to notify the seaweed farmers from Indramayu, West Java, Indonesia. The study data were obtained from all seaweed polyculture farmers populations in the observational location by census containing two farmers groups, namely Gracilaria sp. with milkfish and black tiger shrimp (GMS symbol) and Gracilaria sp. with milkfish (GM symbol) polyculture system. This study resulted that GMS polyculture system obtained higher productivity than GM polyculture system. The GMS business scale was in the increasing return to scale condition, while GM was in the decreasing return to scale condition. The optimal condition of GMS polyculture system was performed by improving the black tiger shrimp seed input, milkfish seed, and milkfish feed, besides declining the working hours, while GM polyculture system was performed by decreasing the milkfish feed and farmers working hours. When the optimal condition is applied to the GMS polyculture system, then the business profit reaches five times, resulting in an increased profit margin of $112 \%$ with $\mathrm{R} / \mathrm{C}$ becomes $134 \%$. Meanwhile, GM polyculture system only reaches $65 \%$ business profit, $65 \%$ profit margin, and $25 \%$ R/C. The investment payback period from both polyculture systems became shorter. The application of production input efficiency on the GMS polyculture system is more prospective than GM polyculture system.
\end{abstract}

Keywords: Black tiger shrimp, milkfish, production optimation, polyculture, profitability, seaweed

\section{INTRODUCTION}

Aquaculture activities strongly support sustainable fisheries development. The 2030's sustainable development goals (SDGs) has established increased economic benefits on the small island development, developing countries, and developed countries in utilizing the sustainable marine resources for fishery and aquaculture activities (Griffin et al. 2019). Aquaculture activities play an important role in fisheries for the national food security, income, and employment creation, besides the foreign exchange acceptance and social-economic development (Asamoah et al. 2013), as well as filling the global fish demand-supply gap that rapidly grows (Kobayashi et al. 2015).

The global aquaculture production in 2016 comprised 80.0 million tons of consumed fish, 30.1 million tons of water plants, and 37,900 tons of non-food products with an estimated selling price of USD 243.5 billion (FAO 2018). The aquaculture contribution in 2030 is proclaimed to be the world's food and nutritional security. The average aquaculture production development over the last three decades increased to $8 \%$ (Kobayashi et al. 2015). The fish production from aquaculture in 2030 is predicted to become 109 million tons with $37 \%$ growth and is expected to contribute to the world's total fish supply of $62 \%$ (FAO
2018; Kobayashi et al. 2015). Indonesia becomes the second country's top contributor to the aquaculture production after China (Cai and Zhou 2019), with the increased production expecting to reach $70.0 \%$ in 2030 (FAO 2018).

Seaweed is one of the world's main aquaculture products as $70 \%$ of the seaweed production is exported as a raw material (dried seaweed), while the remaining (30\%) is processed into carrageenan (Ferdouse et al. 2018). The world's total seaweed production is 30,139 million tons, contributing Gracilaria sp. with 4.15 million tons (13.4\%) and averagely increased into $20.5 \%$ over the last decade. China and Indonesia are by far the main producer of seaweed in the world. Indonesia contributes $38.7 \%$ of the world's seaweed, the second country after China, with a 47.9\% contribution (FAO 2018; Ferdouse et al. 2018).

The aquaculture production of Indonesian in 2018 was 17.25 million tons, containing 10.4 million tons of seaweeds (9.4 million tons of Eucheuma cottonii and 1.0 ton of Gracilaria sp.), 1.4 million tons of shrimp, and 0.8 million tons of milkfish. The national production of seaweed provides $60 \%$ share of Indonesian aquaculture production (DJPB 2018). Gracilaria sp. is the key ingredient for making agarase (Faturrahman et al. 2011) as a source of foodstuffs and industrial resources. Along with 
the increased production, the world market demand also annually increases by 3-5\% (Bixler and Porse 2011), as Ferdouse et al. (2018) added that the demand has increased to $8 \%$ per year, therefore needs to be more upgraded.

Gracilaria sp. seaweed is largely cultured in smallscale ponds with low harvest production (Yang et al. 2015). Gracilaria sp. culture in ponds with a polyculture system is one of the seaweed potential culture systems in Indonesia. This polyculture is the direct polyculture type as the simplest type of co-culture that can be done on almost all aquaculture activities. Polyculture has benefits in reducing the aquaculture water quality impacts, improving the production yield of commercially and economically beneficial species (Martinez-Porchas et al. 2010; Neori et al. 2017). Seaweed polyculture is effective to reduce the nitrogen waste in the water (Abreu et al. 2011; Liu et al. 2016; Duan et al. 2019) and monitor of the aquatic ecosystem (Yang et al. 2015; Zhang et al. 2018; Wang et al. 2020). Seaweed on a polyculture with shrimps can act as bioremediation (Mawi et al. 2020) and can increase endurance and protection against shrimp sickness (Martinez-Porchas et al. 2010). The cultivation of Gracilaria sp. requires small inputs and simple and straightforward technology (WWF 2014; Neori et al. 2017), so it is suitable for use as a cultivation program for community empowerment, and give hope for the improvement of the life of farmers (Kasim and Mustafa 2017). The development of seaweed polyculture is highly recommended as seaweed is very beneficial to improve the aquatic environment and encourage the integrated and environmentally friendly aquaculture (FAO 2018; Mawi et al. 2020).

The Abadi seaweed farmers group located in Indramayu, Indonesia, has successfully cultured the Gracilaria sp. using the polyculture system integrated with milkfish (Chanos chanos) and black tiger shrimp (Penaeus monodon). Increased culture production of Gracilaria sp. does not only improves the seaweed productivity but also needs to be accompanied by the resource-efficient use. The efficiency concept is the economic theory essence, particularly the production economy that implicates the input optimation. Efficiency is crucial to achieving the improvement of production output, as the effort to increase the output can not provide the desired results without efficient resource uses. Efficient aquaculture activities will generate higher revenues and provide opportunities to improve the farmer's welfare.

Thereby, it is necessary to determine whether the polyculture production using Gracilaria sp. performed by the seaweed farmers group has been efficient and optimal. The optimal condition of the aquaculture production system is applied to increase the business profit in the polyculture system and achieve sustainable aquaculture. The input analysis optimation is performed to observe the optimal efficiency of the production factors in producing Gracilaria sp. seaweed. Therefore, this study aimed to analyze the productivity, optimize the production input use, and analyze the profitability of Gracilaria sp. polyculture system with milkfish (Chanos chanos) and black tiger shrimp (Penaeus monodon).

\section{MATERIALS AND METHODS}

\section{Study area}

This study was conducted on the main seaweed producers in Indramayu Regency, West Java, Indonesia, located at position $6^{0} 18^{\prime} 04^{\prime \prime} \mathrm{S}-6^{0} 18^{\prime} 55^{\prime \prime} \mathrm{S}$ and $108^{0} 11^{\prime} 37^{\prime \prime}$ E $-108^{0} 13^{\prime} 28^{\prime \prime} \mathrm{E}$.

\section{Procedures}

\section{Data collection}

This study was conducted to observe the differences between two polyculture systems, namely seaweed (Gracilaria sp.) with milkfish (Chanos chanos) and seaweed (Gracilaria sp.) with milkfish (Chanos chanos) and black tiger shrimp (Penaeus monodon) polyculture system. Data were collected through the survey method from the Gracilaria sp. seaweed farmers. The data were collected from all seaweed farmers populations in the study location by census containing two different farmers groups. Gracilaria sp. seaweed polyculture with milkfish and black tiger shrimp (GMS symbol) was 13 farmers, while Gracilaria sp. with milkfish (GM symbol) was 29 farmers. Data were obtained through the observation method and following all cultural activities performed by the farmers, as well as conducting a structural interview with the farmers.

\section{Characteristics of farmers and production performance}

Characteristics of farmers are conducted by interviews to obtain data on sex, age, education, and the number of family dependents. The general illustration of the Gracilaria sp. seaweed production was performed on GMS and GM polyculture system by calculating the initial weight and final weight Gracilaria sp. Seaweed weight measurement was performed once every 15 days with the analytical scales at $0.1 \mathrm{~g}$ accuracy. The production performance parameters determined were the weightspecific growth rate and the production result (yield) of Gracilaria sp., milkfish, and black tiger shrimp. The specific growth rate (SGR) was calculated according to Huisman (1987): SGR weight $(\% /$ day $)=[(\ln \mathrm{Wt}-\ln \mathrm{W} 0) / \mathrm{t}]$ $\mathrm{x} 100$, whereas W0 and Wt are the initial and final weight of the fish $(\mathrm{g})$ and $\mathrm{t}$ is the culture period in days.

\section{Water quality}

The water quality was measured once every 15 days containing salinity, temperature, $\mathrm{pH}$, and DO. Temperature and DO were measured using DO meter, while $\mathrm{pH}$ was measured using $\mathrm{pH}$ meter, and salinity was measured using the refractometer. The measurement result of the water quality parameters can be seen in Table 1 .

Table 1. Water quality parameters

\begin{tabular}{lll}
\hline Parameters & GMS & GM \\
\hline Salinity $\left(\mathrm{g} \mathrm{L}^{-1}\right)$ & $15.0-20.0$ & $20.0-24.0$ \\
$\mathrm{pH}$ & $7.6-8.4$ & $7.7-8.2$ \\
Dissolved oxygen $\left(\mathrm{mg} \mathrm{L}^{-1}\right)$ & $4.5-6.5$ & $4.6-5.5$ \\
Temperature $\left({ }^{\circ} \mathrm{C}\right)$ & $28.8-31.5$ & $29.6-34.0$ \\
\hline
\end{tabular}




\section{Production optimation analysis}

Production optimation analysis used the Cobb-Douglas production function approach (Wang and Fu 2013), which generally represents the input and output relationship (Ali et al. 2018). The Cobb-Douglas production function was determined using the Ordinary Least Square (OLS) method as one of the double linear regression methods to determine the free variable influences against the bound variables (Pavelescu, 2004). Cobb-Douglas function equation can be mathematically presented as:

$$
\begin{aligned}
& \mathrm{Y}=\mathrm{aX}_{1}{ }^{\mathrm{b} 1} \mathrm{X}_{2}^{\mathrm{b} 2} \mathrm{X}_{3}^{\mathrm{b} 3} \mathrm{X}_{4}{ }^{\mathrm{b} 4} \mathrm{X}_{5}^{\mathrm{b} 5} \mathrm{X}_{6}^{\mathrm{b} 6} \mathrm{X}_{7}^{\mathrm{b} 7} \mathrm{X}_{8}{ }^{\mathrm{b} 8} \mathrm{U} \\
& \text { Where: } \\
& \mathrm{Y} \quad \text { : Production }\left(\mathrm{kg} \mathrm{ha}^{-1}\right) \\
& \text { a : Intercept } \\
& b_{i} \quad: \text { Regression coefficient }(i=1,2,3 \ldots n) \\
& \mathrm{X}_{1} \quad \text { : Seaweed seed }\left(\mathrm{kg} \mathrm{ha}^{-1}\right) \\
& \mathrm{X}_{2} \text { : Black tiger shrimp seed PL } 10\left(\text { shrimp ha }{ }^{-1}\right) \\
& \mathrm{X}_{3} \quad \text { : Milkfish seed (fish ha }{ }^{-1} \text { ) } \\
& \mathrm{X}_{4} \quad \text { : Milkfish feed }\left(\mathrm{kg} \mathrm{ha}^{-1}\right) \\
& \mathrm{X}_{5} \quad \text { : Fertilizer for seaweed }\left(\mathrm{kg} \mathrm{ha}^{-1}\right) \\
& \mathrm{X}_{6} \quad \text { : Feed supplement for milkfish }\left(\mathrm{kg} \mathrm{ha}^{-1}\right) \\
& \left.\mathrm{X}_{7} \quad \text { : Working hours (hour ha-1 }{ }^{-1}\right) \\
& \mathrm{X}_{8} \quad \text { : Pesticide }\left(\mathrm{L} \mathrm{ha}^{-1}\right) \\
& \mathrm{U} \text { : Error term }
\end{aligned}
$$

The stepwise method was used to obtain the best regression model (Wang and Chen, 2016). The return to scale (RTS) analysis was used to determine the Gracilaria sp. culture business scale. There are three business conditions based on the RTS analysis, namely increasing return to scale, constant return to scale, and decreasing return to scale. Increasing return to scale means that the additional production factors are greater when $\sum \mathrm{bi}>1$. The constant return to scale means that the additional production factor is proportional when $\sum b i=1$. Decreasing return to scale means that the additional production factor is smaller when $\sum b i<1$.

Production optimation will be achieved when the marginal value of an input product is equal to the input price (Das et al. 2016; Rahaman et al. 2015). The ratio between the marginal value product (MVP) and the input price per unit $(\mathrm{P})$ indicates the production input efficiency. When MVP/P>1, the input use is non-optimal, therefore needs to be added to achieve the optimal conditions, while $\mathrm{MVP} / \mathrm{P}=1$ means that the input use is optimal, therefore can be continuously proceeded, and MVP/P $<1$ means the nonoptimal input use, therefore needs to be decreased to achieve the optimal condition.

\section{Profitability analysis}

The profitability analysis was performed to determine the profit value obtained from the seaweed culture using GMS and GM polyculture systems. The profitability analysis comprises the investment (I), fixed cost (FC), variable cost (VC), total cost (TC), total revenue (TR), profit (TR-TC), profit margin (profit/TR x 100\%), revenuecost ratio (TR/TC), and payback period (I/profit x 1 year).

\section{Assumption calculation}

The calculation of profitability analysis used two calculation approaches, namely the actual approach with the real data obtained from the farmers and the optimal approach calculated based on the optimation analysis result from the Cobb-Douglas production function (Table 2).

\section{RESULTS AND DISCUSSION}

\section{Farmers characteristics}

Gracilaria sp. seaweed using the polyculture system becomes the main job for most farmers with the experience reaching 5-20 years. The farmers learned the polyculture system from the other farmers. The seaweed farmers' characteristics can be seen in Table 3 .

\section{Production performance}

\begin{tabular}{|c|c|c|c|c|}
\hline \multirow{2}{*}{ Assumption } & \multicolumn{2}{|c|}{ GMS } & \multicolumn{2}{|c|}{ GM } \\
\hline & Actual & Optimal & Actual & Optimal \\
\hline Seaweed seed (kg) & $3,821.90$ & $3,821.90$ & $3,707.00$ & $3,707.00$ \\
\hline Black tiger shrimp seed (seed) & $12,954.00$ & $97,131.80$ & - & - \\
\hline Milkfish seed (seed) & $3,700.00$ & $7,678.00$ & $3,655.00$ & $3,655.00$ \\
\hline Seaweed production $(\mathrm{kg})$ & $1,025.20$ & $1,025.20$ & $1,245.70$ & $1,245.70$ \\
\hline Seaweed cycle $\left(\right.$ cycle year $\left.^{-1}\right)$ & 6 & 6 & 6 & 6 \\
\hline Black tiger shrimp production $(\mathrm{kg})$ & 109.20 & 728.50 & - & - \\
\hline Black tiger shrimp cycle (cycle year ${ }^{-1}$ ) & 2 & 2 & - & - \\
\hline Milkfish production $(\mathrm{kg})$ & $1,189.80$ & $2,457.10$ & $1,150.50$ & $1,150.50$ \\
\hline Milkfish cycle (cycle year $\left.{ }^{-1}\right)$ & 2 & 2 & 2 & 2 \\
\hline Dried seaweed price (USD kg-1 $)$ & 0.29 & 0.29 & 0.29 & 0.29 \\
\hline Milkfish price (USD kg $\left.{ }^{-1}\right)$ & 2.16 & 2.16 & 2.16 & 2.16 \\
\hline Black tiger shrimp price (USD kg-1) & 7.18 & 7.18 & - & - \\
\hline
\end{tabular}

Aquaculture activities of Gracilaria sp. with milkfish and black tiger shrimp polyculture is performed traditionally, starting from the pond preparation, seed stocking, maintenance, and harvesting. Soil ponds are used with $1.5 \mathrm{ha}$ area and $100 \mathrm{~cm}$ water height per each pond. Seaweed seeds are planted using the off-bottom method by spreading the seaweed at certain points with $1 \mathrm{~m}$ distance, as one point can contain 1-2 kg seed. Milkfish and black tiger shrimp seeds are usually stocked after seven days of seaweed stocking. Seaweeds are fertilized after two weeks of stocking with $11.7 \pm 7 \mathrm{~kg} \mathrm{ha}^{-1}$ doze in GMS polyculture system and $10.6 \pm 4.6 \mathrm{~kg} \mathrm{ha}^{-1}$ on GM polyculture system.

Table 2. Culture assumption of Gracilaria sp. seaweed polyculture system per-hectare

Note: USD 1= IDR 13,945 in August 2019 
The pesticides are applied to eradicate pests in the pond with $500 \mathrm{ml} \mathrm{ha}^{-1}$ doze. Fish are fed once a day with $a$ satiation method. In addition, feed supplement is also given to increase the milkfish appetite at $5.6 \pm 2.8 \mathrm{~kg} \mathrm{ha}^{-1}$ doze in GMS polyculture system and $4.4 \pm 2.9 \mathrm{~kg} \mathrm{ha}^{-1}$ in GM polyculture system. The seaweed harvesting is performed after 45 days of maintenance and sold as dried seaweed. Wet harvested seaweeds are dried and generally have a $10 \%$ yield. The harvesting of milkfish and black tiger shrimp are performed twice a year.

The production performance of Gracilaria sp. is different in both observed polyculture systems. GMS polyculture system showed better production performance than GM polyculture system. Gracilaria sp. seaweed polyculture performance is presented in Table 4 .

\section{Production optimation}

Some variables affecting the production function in the GMS polyculture system are the black tiger shrimp seed $\left(\mathrm{X}_{2}\right)$, milkfish seed $\left(\mathrm{X}_{3}\right)$, milkfish feed $\left(\mathrm{X}_{4}\right)$, and working hours $\left(\mathrm{X}_{7}\right)$ as presented on Table 5 . Based on the processed data results using the OLS method, the p-value $<0.15$ shows the $X_{2}, X_{3}, X_{4}$, and $X_{7}$ had a significant effect on the production of seaweed polyculture with GMS system at an 85\% degree of confidence level, while GM polyculture system is influenced by milkfish feed $\left(\mathrm{X}_{4}\right)$ and working hours $\left(\mathrm{X}_{7}\right)$. The Cobb-Douglas estimated production function of Gracilaria sp. seaweed polyculture is presented in Table 5 .

The Cobb-Douglas model of the estimated production function shows the determination coefficient $\left(\mathrm{R}^{2}\right)$ of $85 \%$, indicating that the polyculture variations in GMS production system can be $85 \%$ simultaneously described through the milkfish seeds, black tiger shrimp seeds, milkfish feed, and working hours. The remaining $(15 \%)$ is described by the other factors outside of the model. GM system produces the determination coefficient $\left(\mathrm{R}^{2}\right)$ of $84.81 \%$, indicating that the production of GM can be $84.81 \%$ simultaneously described by the milkfish feed and working hours, while $15.19 \%$ remaining is described by other factors.

Tabel 3. The Gracilaria sp. seaweed polyculture farmers characteristics

\begin{tabular}{lcc}
\hline \multicolumn{1}{c}{ Characteristics } & GMS & GM \\
\hline Gender & 12 & 29 \\
Male & 1 & 0 \\
Female & & \\
Age (year) & 1 & 5 \\
< 30 year & 9 & 16 \\
31-45 year & 3 & 6 \\
46-60 year & 0 & 2 \\
> 61 year & & \\
Education & 1 & 1 \\
No school & 5 & 10 \\
Elementary school & 3 & 13 \\
Middle school & 3 & 5 \\
High school & 1 & 0 \\
Bachelor school & & \\
Family & 10 & 24 \\
1-4 people & 3 & 5 \\
5-7 people & & \\
\hline
\end{tabular}

Table 4. The Gracilaria sp. seaweed polyculture production performance

\begin{tabular}{|c|c|c|}
\hline Parameters & GMS & GM \\
\hline Socking density Gracilaria $\left(\mathrm{kg} \mathrm{ha}^{-1}\right)$ & $3.800 \pm 220$ & $3.475 \pm 100$ \\
\hline Initial weight Gracilaria $\left(\mathrm{kg} \mathrm{m}^{-2}\right)$ & $1.00 \pm 0.00$ & $1.00 \pm 0.00$ \\
\hline Final weight Gracilaria $\left(\mathrm{kg} \mathrm{m}^{-2}\right)$ & $2.00 \pm 0.50$ & $1.90 \pm 0.40$ \\
\hline Stocking density black tiger shrimp ( PL10 fish ha ${ }^{-1}$ ) & $12.950 \pm 750$ & - \\
\hline Stocking density milkfish (fish ha $\left.{ }^{-1}\right)$ & $3.700 \pm 160$ & $3.655 \pm 165$ \\
\hline Specific growth rate (SGR) Gracilaria (\% hari ${ }^{-1}$ ) & $1.60 \pm 0,31$ & $1.44 \pm 0,13$ \\
\hline Yield Gracilaria (wet kg ha-1) & $12.450 \pm 5980$ & $10.250 \pm 4500$ \\
\hline Yield Gracilaria (dry kg ha"-1) & $1.245 \pm 590$ & $1.025 \pm 450$ \\
\hline Yield black tiger shrimp $\left(\mathrm{kg} \mathrm{ha}^{-1}\right)$ & $150 \pm 20$ & - \\
\hline Yield milkfish $\left(\mathrm{kg} \mathrm{ha}^{-1}\right)$ & $1.500 \pm 110$ & $1.000 \pm 77$ \\
\hline
\end{tabular}

Table 5. The Cobb-Douglas estimated production function of Gracilaria sp. seaweed polyculture

\begin{tabular}{|c|c|c|c|c|}
\hline \multirow{2}{*}{ Variables } & \multicolumn{2}{|l|}{ GMS } & \multicolumn{2}{|l|}{ GM } \\
\hline & Regression coeffient & P-value & Regression coeffient & P-value \\
\hline Intercept & 9.567 & 0.000 & 10.826 & 0.000 \\
\hline $\mathrm{X}_{2}$ (Black tiger shrimp seed) & $0.184^{*}$ & 0.143 & & \\
\hline $\mathrm{X}_{3}$ (Milkfish seed) & $0.249^{*}$ & 0.108 & & \\
\hline $\mathrm{X}_{4}$ (Milkfish feed) & $0.350^{*}$ & 0.021 & $0.569^{*}$ & 0.000 \\
\hline $\mathrm{X}_{7}$ (Working hours) & $0.280^{*}$ & 0.102 & $0.373^{*}$ & 0.000 \\
\hline Standard error & 0.15 & & 0.11 & \\
\hline R-squared (\%) & 85.0 & & 84.81 & \\
\hline Adjusted R-squared (\%) & 77.5 & & 83.67 & \\
\hline
\end{tabular}

Note: ${ }^{*}$ Significant difference in $85 \%$ 
The function model of Gracilaria sp. seaweed polyculture with GMS system produces the equation below:

$$
\mathrm{Y}=9.567 \cdot \mathrm{X}_{2}^{(0.184)} \cdot \mathrm{X}_{3}^{(0.249)} \cdot \mathrm{X}_{4}^{(0.350)} \cdot \mathrm{X}_{7}^{(0.280)}
$$

The RTS analysis based on the elasticity of $\mathrm{X}_{2}$ (black tiger shrimp seed), $X_{3}$ (milkfish seed), $X_{4}$ (milkfish feed), and $X_{7}$ (working hours) is 1.063. This shows that the GMS polyculture system business is on the condition of increasing return to scale, which means that the addition of production input will increase the output.

The function model of Gracilaria sp. seaweed polyculture with GM system produces the following equation:

$$
\mathrm{Y}=10.826 \cdot \mathrm{X}_{4}^{(0.569)} \cdot \mathrm{X}_{7}^{(0.373)}
$$

The RTS analysis shows that the GM polyculture system is on the condition of decreasing return to scale, as indicated by the elasticity of $\mathrm{X}_{4}$ and $\mathrm{X}_{7}$ is 0.942 , which means that each addition of production input will lower the output.

The optimal production input use is basically to obtain optimal business conditions. The input efficiency value of Gracilaria sp. seaweed polyculture system is presented in Table 6.

The calculation result of production optimation shows that the Gracilaria sp. seaweed polyculture with GMS system has MVP/P > 1 ratio on black tiger shrimp, milkfish seed, and milkfish feed with 7.498, 2.063, and 1.516 respectively, indicating that the input use is yet nonoptimal, which needs more additions to achieve the optimal value. The working hours have an MVP value of 0.595 (< 1), which indicates excessive working hours input. Therefore it needs to be reduced to achieve the optimal condition. Meanwhile, the value of MVP/P in GM polyculture system on the milkfish feed and working hours have 0.768 and $0.747(<1)$, respectively, which indicates that the use of milkfish feed and working hours should be reduced in order to achieve the optimal conditions.

\section{Profitability analysis}

These polyculture systems require investment costs for purchasing ponds, warehouses, and equipment, such as a shovel, bucket, and others, the fixed costs containing land rent, maintenance, and depreciation, and variable costs containing seeds, feed, fertilizer, pesticides, and working hours. The profit calculation analysis of GMS and GM polyculture is calculated using the assumptions in Table 1, while the profit calculation results in actual and optimal conditions are presented in Table 7.

In GMS polyculture system, the increased total production cost happens due to the changes of the production inputs at the optimal conditions, which can increase the acceptance, resulting in the increased profit value and margin, while increased profit value and margin are obtained from the total cost reduction in GM polyculture system.

Table 6. The input efficiency value of Gracilaria sp. seaweed polyculture

\begin{tabular}{cccccc}
\hline & Inputs & bi & P & MVP & MVP/P \\
\hline \multirow{3}{*}{ GMS } & Black tiger shrimp seed & 0.184 & 0.003 & 0.019 & 7.498 \\
& Milkfish seed & 0.249 & 0.043 & 0.089 & 2.063 \\
& Milkfish feed & 0.350 & 0.406 & 0.616 & 1.516 \\
Working hours & 0.280 & 0.896 & 0.534 & 0.595 \\
& & & & \\
GM & Milkfish feed & 0.569 & 0.406 & 0.312 & 0.768 \\
& Working hours & 0.373 & 0.896 & 0.669 & 0.747 \\
\hline
\end{tabular}

Tabel 7. Profitability analysis of Gracilaria sp. seaweed polyculture in actual and optimal condition

\begin{tabular}{lcccc}
\hline \multirow{2}{*}{ Parameters } & \multicolumn{2}{c}{ GMS } & & GM \\
\cline { 2 - 5 } & Actual & Optimal & Actual & Optimal \\
\hline Investment (USD) & $6.429,93$ & $6.429,93$ & $5.787,78$ & $5.787,78$ \\
Variabel cost (USD) & $3.844,72$ & $4.686,61$ & $4.028,34$ & $2.955,50$ \\
Fixed cost (USD) & $1.743,43$ & $1.743,43$ & $1.405,56$ & $1.405,56$ \\
Total cost (USD) & $5.588,15$ & $6.430,03$ & $5.433,90$ & $4.361,06$ \\
Total Revenue (USD) & $8.450,54$ & $22.784,53$ & $7.094,11$ & $7.094,11$ \\
Profit (USD) & $2.862,40$ & $16.354,49$ & $1.660,21$ & $2.733,05$ \\
Profit margin (\%) & 33,87 & 71,78 & 23,40 & 38,53 \\
R/C & 1,5 & 3,5 & 1,3 & 1,6 \\
Payback Period (year) & 2,2 & 0,4 & 3,5 & 2,1 \\
\hline
\end{tabular}

Note: USD 1= IDR 13,945 in August 2019 
The seaweed farmers are dominated by men around the productive ages (Table 3). The productive age on Gracilaria sp. seaweed polyculture with milkfish and black tiger shrimp (GMS) system is $70 \%$, while on Gracilaria sp. seaweed polyculture with milkfish (GM) system is $55 \%$. The farmer's age will affect the production system and culture management, as the productive age has mature thinking to utilize the resources efficiently and promote better management. This study result shows that the farmer's educational background is relatively low, as GM polyculture system obtains $40 \%$ farmers are the elementary school graduates, while GMS polyculture system obtains $45 \%$ farmers are the junior high school graduates. The educational background usually affects the knowledge, skill, and technological implementation adoption level to support economic development. The number of family members who are dependent on the farmers will affect family welfare, as this study presents that most farmers carry less than four people's dependence.

Seaweed growth is influenced by the availability of major nutritional sources for growth, namely nitrogen and phosphorus. Nitrogen and phosphorus are produced from the remaining metabolic fish and shrimp that will be utilized by seaweed as a source of nutrients for growth. Gracilaria sp. seaweed has the ability to absorb nutrients, especially ammonium and nitrate faster in the aquatic environment (Duan et al. 2019; Mawi et al. 2020).

Therefore GMS polyculture system has more residual waste from the metabolism of milkfish and shrimp than GM polyculture system that only obtains from the milkfish. This affects the specific growth rate (SGR), showing a higher SGR value on GMS polyculture system than GM polyculture system. Based on Table 4, SGR obtained from the GMS and GM polyculture system was $1.60 \pm 0.31$ and $1.44 \pm 0.13 \%$ day $^{-1}$, respectively. This result was higher than Rejeki et al. (2018), who reported that the SGR of $G$. verrucosa cultured in the pond was $1.0 \pm 0.3 \%$ day $^{-1}$ and Lee et al. (2019), who reported that the SGR of G. changii was $0.74 \pm 0.25 \%$ day $^{-1}$. Temperature and salinity are the main factors of seaweed growth. The temperature range in the GMS polyculture system was $28.8-31.5^{\circ} \mathrm{C}$ and $\mathrm{GM}$ was $29.6-34.0^{\circ} \mathrm{C}$, while the salinity range of GMS was 15.0- $20.0 \mathrm{gL}^{-1}$ and $\mathrm{GM}$ was 20.0- $24.0 \mathrm{gL}^{-1}$, as all parameters were good for the seaweed growth (WWF 2014).

The Cobb-Douglas production function analysis (Table 5) shows that significant variables against the GMS production result are black tiger shrimp seed $\left(\mathrm{X}_{2}\right)$, milkfish seed $\left(\mathrm{X}_{3}\right)$, milkfish feed $\left(\mathrm{X}_{4}\right)$, and working hours $\left(\mathrm{X}_{7}\right)$, while GM production variables are milkfish feed $\left(\mathrm{X}_{4}\right)$ and working hours $\left(\mathrm{X}_{7}\right)$. The elasticity value of GMS (Model 1) has a positive coefficient value, as $\mathrm{X}_{2}$ is 0.184 , which means the one unit input addition of $X_{2}$ (black tiger shrimp seed) will increase the production output result of 0.184 units. Likewise, one unit input of $\mathrm{X}_{3}, \mathrm{X}_{4}$, and $\mathrm{X}_{7}$ will also increase the production by $0.249,0.350$, and 0.280 units, respectively. GM polyculture equation (Model 2) shows the elasticity value of $\mathrm{X}_{4}$ and $\mathrm{X} 7$ respectively at 0.569 and 0.373 , which means that increased milkfish feed and working hours will increase the production output by 0.569 and 0.373 units, respectively.

The RTS analysis resulted from the elasticity of GMS is 1.063 (> 1), called the increasing return to scale condition, indicating fewer input resources, therefore increased production output can be done through with the addition of production input. In contrast, the GM system gains an elasticity value of $0.942(<1)$, called the decreasing return to scale condition, indicating more input resources. Therefore reduced production input can be done to obtain the increased output. The optimal input use is aimed to achieve the input efficiency, resulting in the high return value. The optimal condition of GMS polyculture system can be achieved by increasing the milkfish seed, black tiger shrimp seed, and milkfish feed (MVP/P > 1), while the working hours should be reduced as the analysis results indicates the value of MVP/P for the working hours is < 1 (Table 6), indicating that there is an excess of working hours. The allocation of working hours is non-optimal due to the routine activities only performs by one-time feeding activity in the morning and maintenance monitoring in the morning and afternoon, while the wage paid is calculated as the full day activities ( 8 hours), making it become inefficient. In GM polyculture system, variables having $\mathrm{MVP} / \mathrm{P}<1$ are the milkfish feed and working hours; therefore, it should be reduced to reach the optimal conditions, while other variables have been on the optimal condition. Milkfish fish feed on GM polyculture system is inefficient because at satiation feeding is immeasurable and relatively depends on the farmer's preference to decide whether the fish are full or not.

The profit analysis is calculated by comparing the actual conditions based on the location of the polyculture system at the time of the study and optimal conditions based on the value obtained from the analysis of production optimation results using the Cobb-Douglas production function. The result of probability analysis (Table 7) indicates that there is a significant difference between actual and optimal conditions. In GMS polyculture system, an increased number of production inputs (variable costs) on the optimal condition leads to an increased total production cost by $15 \%$ along with the increased total revenue by $170 \%$, resulting in an increased profit five times along with the increased profit margin by $112 \%$. Van den Burg et al. (2016) stated that the seaweed culture in the North Sea gained an 11,100 USD yield, which was higher than the reception obtained from the GMS and GM polyculture system in the actual conditions, but lower than GMS polyculture system at the optimal conditions. High acceptance and profit were produced due to the increased number of milkfish seed and black tiger shrimp seed stocked in ponds, thereby increasing the amount of milkfish and black tiger shrimp production. The selling price of black tiger shrimp is quite high to contribute to large acceptance in the polyculture business. This was in accordance with Irz and Mckenzi (2003) that the biggest contribution of the shrimp polyculture with milkfish, crab, and tilapia produced $62 \%$ sale of the total revenue.

GMS polyculture system generates a revenue-cost ratio (R/C) of 1.5 in actual conditions, then increased into 3.5 at optimal conditions, becoming 134\%. Likewise, the value of 
the payback period (PP), which indicates that the returning period of investment in the optimal conditions becomes shorter. The Optimation of GM polyculture production inputs is achieved by the decreased production inputs. This leads to a $20 \%$ total cost-saving but does not change the acceptance value. Profit and profit margin both increased by $65 \%$, while the $\mathrm{R} / \mathrm{C}$ increased from 1.3 in actual condition to 1.6 , reaching $25 \%$ at optimal conditions. Similarly, the optimal condition in the GM polyculture system can reduce the returning period of investment. In general, the profitability value of GMS is higher than GM due to the high economic value of the shrimp cultivated in the GMS polyculture system. Shrimp culture is the most beneficial cultivation as having high commercial value (Martinez-Porchas et al. 2010). Small-scaled shrimp culture produces R/C 1.73 and a $42 \%$ profit margin (Shawon et al. 2018). The study results conducted in Vietnam and Thailand showed the small-scaled culture of $P$. monodon with the low stocking density and extensive technology produced negative net return, which became an unprofitable business (Engle et al. 2017). This study illustrates the seaweed polyculture business that provides higher profit value, which is in accordance with MartinezPorchas et al. (2010) that the polyculture has the potential to increase the economic gain and strategy in the development of integrated, environmentally friendly, and sustainable culture. The application of production input in the seaweed polyculture (GMS) is more prospective than GM polyculture system.

In conclusion, the Gracilaria sp. seaweed polyculture with milkfish and black tiger shrimp produces higher productivity than seaweed polyculture with milkfish. The scale of polyculture with milkfish and black tiger shrimp is in the increasing return to scale condition, while polyculture with milkfish polyculture in decreasing return to scale condition. The optimal condition for obtaining the efficient production inputs in the milkfish and black tiger shrimp polyculture is performed by improving the input of milkfish seed, black tiger shrimp seed, and milkfish feed, besides reducing the working hours. At the seaweed polyculture with milkfish, the optimal input condition is obtained by reducing the amount of the milkfish feed and working hours. The application of production input efficiency in the Gracilaria sp. seaweed polyculture with milkfish and black tiger shrimp is more prospective than in the seaweed polyculture with milkfish.

\section{ACKNOWLEDGEMENTS}

We would like to thank Abadi seaweed farmers group in Cantigi Subdistrict, Indramayu District, West Java, Indonesia, for their assistance and agreement during the study period conducted on their polyculture location.

\section{REFERENCES}

Abreu MH, Pereira R, Yarish C, Buschman AH, Sausa-Pinto I. 2011 IMTA with Gracilaria vermiculophylla: Productivity and nutrient removal performance of the seaweed in a land-based pilot-scale system. Aquacult 312

10.1016/j.aquaculture.2010.12.036.

Ali H, Rahman MM, Murshed-e-Jahan K, Dhar GC. 2018. Productions economics of striped catfish (Pangasianodon hypophthalmus, Sauvage, 1878) farming under polyculture system in Bangladesh. Aquacult 491: 381-390. DOI: 10.1016/j.aquaculture.2017.12.004.

Asamoah EK, Nunoo FKE, Osei-Asare YB, Addo S, Sumaila UR. 2013. A production function analysis of pond aquaculture in Southern Ghana. Aquacult Econ Manag 16: 185-201. DOI: 10.1080/13657305.2012.704616.

Bixler HJ, Porse H. 2011. Decade of change in the seaweed hydrocolloids industry. J Appl Phycol 23: 321-335. DOI: 10.1007/s10811-0109529-3.

Cai J, Zhou X. 2019. Contribution of aquaculture to total fishery production: the 50-percent mark. FAO Aquacult Newslett 60: 43-45.

Das A, Kumar NR, Sharma R, Biswas P. 2016. Return to scale and resource use efficiency in fish production in Tripura. Fish Technol 53: 339-343.

Duan Y, Yang N, Hu M, Wei Z, Bi H, Huo Y. 2019. Growth and nutrient uptake of Gracilaria lemaneiformis under different nutrient conditions with implicationa for ecosystem services: A case study in the laboratory and in an enclosed mariculture area in the East China Sea. Aquat Bot 153: 73-80. DOI: 10.1016/j.aquabot.2018.11.012.

DJPB [Direktorat Jenderal Perikanan Budidaya]. 2018. Laporan kinerja. Direktorat Jenderal Perikanan Budidaya Kementerian Kelautan dan Perikanan. Jakarta. [Indonesian]

Engle CR, Boyd CE, Paungkaew D, Viriyatum R, Tine HQ, Minh HN. 2017. Economics of sustainable intensification of aquaculture: Evidence from shrimp farm in Vietnam and Thailand. J World Aquacult Soc 48 (2): 227-239. DOI: 10.1111/jwas.12423.

FAO [Food and Agriculture Organization of the United Nations]. 2018. The state of world fisheries and aquaculture. Food and Agriculture Organization of the United Nations, Rome.

Faturrahman, Meryandini A, Junior MZ, Rusmana, I. 2011. Isolation and identification of an agar-liquefying marine bacterium and some properties of its extracellular agarases. Biodiversitas 12 (4): 192-197. DOI: $10.13057 /$ biodiv/d120402.

Ferdouse F, Holdt SL, Smith R, Murua P, Yang Z. 2018. The global status of seaweed production, trade, and utilization. FAO Globefish Res Programme 124. Food and Agriculture Organization of the United Nations, Rome.

Griffin W, Wang W, de Souza MC. 2019. The sustainable development goals and the economic contribution of fisheries and aquaculture. FAO Aquacult Newslett 60: 51-52.

Huisman EA. 1987. Principle of Fish Production. Wageningen Agricultural University, Wageningen, NE.

Irz X, Mckenzie V. 2003. Profitability and technical efficiency of aquaculture systems in Pampanga, Philippines. Aquacult Econ Manag 7: 195-211. DOI: 10.1080/13657300309380340.

Kasim M, Mustafa A. 2017. Comparison growth of Kappaphycus alvarezii (Rhodophyta, Solieriaceae) cultivation in floating cage and longline in Indonesia. Aquacult Rep 6: 49-55. DOI: 10.1016/j.aqrep.2017.03.004.

Kobayashi M, Msangi S, Batka M, Vannuccini S, Dey MM, Anderson JL. 2015. Fish to 2030: The role and opportunity for aquaculture. Aquacult Econ Manag 19: 282-300. DOI: 10.1080/13657305.2015.994240.

Lee WK, Lim YY, Ho CL. 2019. pH affects growth, physiology and agar properties of agarophyte Gracilaria changii (Rhodophyta) under low light intensity from Morib, Malaysia. Regional Stud Marine Sci 30: 19. DOI: 10.1016/j.rsma.2019.100738.

Liu H, Wang F, Wang Q, Dong S, Tian X. 2016. A comparative study of the nutrient uptake and growth capacities of seaweeds Caulerpa lentillifera and Gracilaria lichenoides. J Appl Phycol 28: 3083-3089. DOI 10.1007/s10811-016-0858-8.

Martinez-Porchas M, Martinez-Cordova LR, Porchas-Cornejo MA. 2010. Shrimp polyculture: a potentially profitable, sustainable, but uncommon aquacultural practice. Rev Aquacult 2: 73-85. DOI: 10.1111/j.1753-5131.2010.01023.x.

Mawi S, Krishnan S, Din MFMD, Arumugan N, Chelliapan S. 2020. Bioremediation potential of macroalgae Gracilaria edulis and Gracilaria changii co-cultured with shrimp wastewater in an outdoor water recirculation system. Environ Tech Innov 17: 1-8. DOI: 10.1016/j.eti.2019.100571. 
Neori A, Shpigel M, Guttman L, Israel A. 2017. Development of Polyculture and Integrated Multi-Trophic Aquaculture (IMTA) in Israel: A review. Isr J Aquacult - Bamidgeh 69: 1-9.

Pavelescu FM. 2004. Features of the ordinary least square (OLS) method Implication for the estimation methodology. Romanian $\mathrm{J}$ Econ Forecasting 5 (2): 85-101.

Rahaman SM, Ghosh A, Pal S, Nandi S. 2015. A comparison of resource use efficiency and constraints of wastewater and freshwater fish production system in West Bengal. Econ Affairs 60 (2): 249-255. DOI: 10.5958/0976-4666.2015.00037.6.

Rejeki S, Ariyati RW, Widowati LL, Bosma RH. 2018. The effect of three cultivation methods and two seedling types on growth, agar content and gel strength of Gracilaria verrucosa. Egyptian J Aquat Res 44: 65-70. DOI: 10.1016/j.ejar.2018.01.001.

Shawon N, Prodhan MMH, Khan MA, Mitra S. 2018. Financial profitability of small scale shrimp farming in a coastal area of Bangladesh. J Bangladesh Agricult Univ 16 (1): 104-110. DOI: 10.3329/jbau.v16i1.36490.

Van den Burg SWK, Van Duijn AP, Bertelings H, Van Krimpen MM, Poelman M. 2016. The economic feasibility of seaweed production in the North Sea. Aquacult Econ Manag 20: 235-252. DOI: 10.1080/13657305.2016.1177859.
Wang K, Chen Z. 2016. Stepwise regression and all possible subsets regression in education. Electr Intl J Educ Arts Sci 2 (1): 60-81.

Wang X, Fu Y. 2013. Some characterizations of the Cobb-Douglas and CES production functions in microeconomics. Abstract Appl Analysis 2013: 1-6. DOI: 10.1155/2013/761832.

Wang X, He L, Ma Y, Huan L, Wang Y, Xi B, Wang G. 2020 Economically important red algae resources along the Chinese coast: History, status, and prospects for their utilization (Review article). Algal Res 46: 1-14. DOI: 10.1016/j.algal.2020.101817.

WWF [World Wildlife Fund]. 2014. Budidaya Rumput Laut Gracilaria sp. di Tambak. WWF Indonesia, Jakarta. [Indonesian]

Yang Y, Chai Z, Wang Q, Chen W, He Z, Jiang S. 2015. Cultivation of seaweed Gracilaria in Chinese coastal water and its contribution to environmental improvements (Review article). Algal Res 9: 236-244. DOI: 10.1016/j.algal.2015.03.017.

Zhang A, Wen X, Yang X, He X, Su H, Tang H, Jordan RW, Wang Y, Jiang S. 2018. Response of microalga to large-seaweed cultivation as revealed by particulate organic matter from an integrated aquaculture off Nan'ao Island. Mar Pollut Bull 133: 137-143. DOI: 10.1016/j.marpolbul.2018.05.026. 